\title{
The Ecology of the Vaginal Flora at First Prenatal Visit is Associated with Preterm Delivery and Low Birth Weight
}

\author{
Gilbert G.G. Donders ${ }^{*}, 1,2$, Bernard Spitz ${ }^{1}$, Annie Vereecken ${ }^{3}$, Ben Van Bulck ${ }^{4}$, Ann Cornelis ${ }^{2}$, \\ Alfons Dekeersmaeker ${ }^{3}$, Patrick Klerckx ${ }^{3}$, Lieven Londers ${ }^{5}$ and Jos Caudron ${ }^{5}$ \\ ${ }^{1}$ Departments of $O B / G Y N$ and Pathology of Univ. Hosp. Gasthuisberg, Leuven, ${ }^{2}$ A.Z. Heilig Hart Tienen, ${ }^{3}$ Laboratory \\ for Clinical Pathology, Antwerpen, ${ }^{4}$ A.Z. Erasmus, Antwerpen and ${ }^{5}$ A.Z. Blasius Dendermonde, Belgium
}

\begin{abstract}
Objective: Can assessment of vaginal microbial flora at first prenatal visit predict the outcome of pregnancy?
Material and methods: Pap smears and vaginal cultures were taken from 222 pregnant women at their first prenatal visit. Lactobacillary grades (LBG I-III) on Pap smears were used as a basis for the scoring. Points were added or subtracted according to the morphotypes of the lactobacilli, the presence of abnormal cellular morphology, increased vaginal leukocytosis, visible pathogens or red blood cells, or the finding of cytolysis of epithelial cells. The total score, reflecting the health of the vaginal microflora, was termed "Vaginal Ecology Score (VECO score)" and compared with pregnancy outcome.

Results: A strong correlation was found between the vaginal eco-score (VECO) at first prenatal visit and the birth weight $\left(\mathrm{r}^{2} 0.85, \mathrm{p}=0.003\right)$, and between the VECO score and the number of days before term delivery took place $\left(\mathrm{r}^{2} 0.57, \mathrm{p}=\right.$ 0.048). This association persisted after multivariate analysis. After standardization for positive vaginal culture, a VECO score of 4 or more at first visit was associated with lower birth weight, earlier delivery and smaller fetal head circumference, but not with histological chorioamnionitis. Chorioamnionitis, on the other hand, was found more often in the group with positive vaginal cultures at first prenatal visit.

Discussion: Vaginal micro-ecology can be scored at the first antenatal visit to predict delivery before 40 weeks and lowered birth weight, even in the absence of overt or detectable infectious disease. To assess prematurity below 37 weeks, larger studies are needed. This assessment of the vaginal ecology could also easily be applied on fresh wet mounts or gram stained specimens of vaginal fluid.
\end{abstract}

\section{INTRODUCTION}

Worldwide, preterm delivery remains a major complication of pregnancy and is the main cause of perinatal mortality, and neonatal and maternal morbidity. Over time, it has become increasingly clear that ascending infection from the vagina and cervix can lead to overt chorioamnionitis, subclinical intra-amniotic infection and preterm delivery [1]. The more remote from term a delivery occurs, the higher the likelihood of an underlying chorioamnionitis, positive amniotic cultures, and increased production of pro-inflammatory cytokines and prostaglandins $[1,2]$.

A lot of energy has been put into the early detection of infectious parameters that enable obstetricians to screen pregnant women and select those at high risk of preterm delivery. There is growing evidence that early treatment with adequate antibiotics is more convincing than the use of agressive tocolytics in preventing at least part of the otherwise intractable, so-called 'idiopathic' premature labor $[1,3]$.

*Address correspondence to this author at the Department of Obstetrics and Gynecology, University Hospital, Gasthuisberg, Katholieke Universiteit Leuven, Herestraat 49 3000, Leuven, Belgium; Tel: +32 163442 04;

Fax: +32 168227 14; E-mail: gilbert.donders@femicare.net
Although selective diagnosis and eradication of specific pathogens from the lower genital tract may prevent ascending or hematogenous infection and interrupt the cascade ultimately leading to amnionitis and preterm birth in a highly endemic area, the benefits of such screening techniques are much less clear in areas of the world where the prevalence of such infections is low.

Using the lactobacillary grading of the vaginal microflora in a population with high prevalence of genital infection [4, 5], we previously demonstrated the link between nonspecific disturbance of the vaginal flora early in pregnancy and first trimester miscarriage, preterm birth and low birth weight [6-10]. The association of (anaerobic) bacterial vaginosis and preterm birth has been repeatedly confirmed [11$15]$, and treatment with oral clindamycin $[12,14]$, or oral metronidazole [16] has proven to be effective in delaying delivery. However, other studies did not find any effect of $\mathrm{BV}$ on the incidence rate of preterm birth [10], nor could they diminish the risk of preterm rupture of the membranes, chorioamnionitis or preterm birth by treatment with oral metronidazole [17].

In this paper we argue that in a population with a known low risk of genital infection, aspecific abnormalities of the lactobacillary morphotypes on Pap smears and the inflamma- 
tory reaction present in the vagina have a significant impact on the pregnancy outcome. The disturbed vaginal ecosystem was molded into a practical variable, coined vaginal ecoscore (VECO score). This new score is distinct from bacterial vaginosis, is not costly to obtain and is easy to perform, even by non-specialists. In the group of women studied, clinical (anaerobic) bacterial vaginosis as such was not associated with preterm delivery or with low birth weight.

\section{MATERIAL AND METHODS}

General outline and patient selection. In a central area of Flanders, where prevalence of genital tract infection with Trichomonas vaginalis, Neisseria gonorrhoeae, syphilis, and Chlamydia trachomatis among normal pregnant women is below 2 percent, 222 consecutive pregnant Caucasian women presenting for a first routine prenatal visit were enrolled. The aim of the study was to determine which microscopical parameter on the Pap smear would be helpful in the detection of an increased risk of preterm birth and chorioamnionitis.

At the first prenatal visit, dating according to the last menstrual period was confirmed by vaginal ultrasound when gestation was less than 14 weeks, or by abdominal ultrasound when gestation was above 14 weeks. If the expected date of delivery differed by more than one week from that suggested by ultrasound examination, a second scan was performed after two to four weeks, before correction of the expected date of delivery was permitted.

History taking and specimen sampling. A detailed history was taken, including recent use of antibiotics or of any vaginal medication and any signs of possible genital infection. Before lubricants were used or vaginal examinations performed, a sterile speculum was introduced for sampling ectocervical and high vaginal smears by use of a wooden Ayre spatula, followed by a combined endocervicalendovaginal swab for culture. The Ayre spatula was then spread on to two separate glass slides and immediately fixed by a commercial fixative spray for further Papanicolaou staining.

After the ectocervix had been swabbed, a cotton-tipped amalgan swab for Chlamydia culture was then introduced into the cervix, allowed to soak for 15 seconds, and turned thrice inside the endocervical canal.

A venous blood sample was taken for routine pregnancy testing, and for detection of anti-Chlamydia antibodies.

Microbiology. The cotton swab was plated onto chocolate agar no later than 4 hours after collection and was incubated aerobically for 48 hours at $37^{\circ} \mathrm{C}$. Detection of the pathogens present was performed according to standard microbiological techniques. No special plates were used for detection of group B streptococci, as growth considered to be clinically important would be adequately expressed on blood agar. Gardnerella vaginalis was cultured for 48 hours at $37^{\circ} \mathrm{C}$ on blood agar $(7 \%$ human blood, gentamycin $4 \mathrm{mg} / \mathrm{l}$, Nalidixin acid $30 \mathrm{mg} / \mathrm{l}$, Amphotericin B 2mg/l). Ureaplasma urealyticum and Mycoplasma hominis were cultured on specific commercial media. Swabs for $C$. trachomatis were transported in cell transport medium and incubated for 72 hours on McCoy cell lines.
In the serum samples, specific anti-Chlamydia IgG and $\operatorname{IgM}$ antibodies were measured. A titer greater than 60 units/ml was considered positive. The origin of the antiChlamydia antibodies ( $C$. psittaci or $C$. trachomatis) could not be recovered, but in this and previous work we found a good correlation between $\operatorname{IgG}, \operatorname{IgA}$ and cervical antigen or positive cultures, indicating that the vast majority of the positive anti-Chlamydia IgG originate from genital infection by C. trachomatis.

Pap smears variables. Microscopy was performed at 400 times magnification (Leitz biomed cold light transmission microscope). Information about the findings on the Pap smears was only reported when it concerned epithelial cell dysplasia, which occurred in 3 women (2 light dysplasia, 1 moderate dysplasia). In another 4 women numerous dark staining cytoplasmic inclusion granules were found in otherwise normal cells ('cobble stones'). They resembled pseudo-hyalin keratin nodules. Women expressing these 'cobble stones' were grouped together with the 3 women having cervical dysplasia and all were referred to as having 'cellular abnormality'.

Other criteria that we marked on the Pap smears were 1) the lactobacillary grades expressed according to Schröder and Donders $[4,5]$, as grade I, being a normal, healthy looking flora with abundant lactobacilli present, grade II as an intermediate flora with a mixture of coccoid bacteria and decreased number of lactobacilli, and grade III, with completely disturbed microflora and virtually no lactobacilli present, 2) the morphology of the lactobacilli (if present) as normal, slender leptosomic and short, coarse types, 3) the background appearance as clean, dirty or spawned with red blood cells or plasma, 4) the presence of cytoplasmic disruption of epithelial cells, leaving behind the bare nucleus surrounded by fragments of cytoplasmic debris (cytolysis), 5) the number of inflammatory cells present, expressed as less than 10 per high power field (400 times magnification), more than 10 per hpf, but less than 10 per epithelial cell, and 10 or more than 10 per epithelial cell.

Finally the clue cells and a specific granular background, suggestive of bacterial vaginosis, sporae or pseudohyphae suggestive of candidiasis and the presence of colonization with cocci were recorded.

Bacterial vaginosis was diagnosed when the complaints of homogenous discharge or fishy odor were combined with either clue cells or a positive culture for Gardnerella vaginalis. Vaginal $\mathrm{pH}$ was not measured. In two of the 18 cases harboring bacterial vaginosis, cultures for $G$. vaginalis were negative, although clinical exam and both fresh and Pap smear microscopy left no doubt about the presence of a cluecell positive discharge [18].

Patient follow-up and outcome variables. Patients were followed according to standard obstetrical care. Complications of ongoing pregnancy were recorded such as admission to hospital for pre-eclampsia, premature labor or other reasons. Patients delivering before 20 completed pregnancy weeks were excluded from further analysis, as were those admitted or treated for pre-eclampsia $(n=10)$. Two twin pregnancies and 10 women on which data from the pregnancy follow-up and/or delivery were incomplete were also excluded. Full analysis could be performed on 173 women. 
Placenta and membranes were available for histological examination in 134 (77.5\%) of the women. Chorioamnionitis was diagnosed as the infiltration of mononuclear or polymorphic lymphocytes in the chorion.

The following outcome variables were analyzed: 1) mode of delivery (vaginal or by cesarean section), 2) days remote from term at delivery, 3) birth weight, 4) neonatal head circumference, 5) duration of the rupture of the fetal membranes before delivery, 6) histology of placenta, umbilical cord and fetal membranes, 7) postnatal Apgar scores after 1 and 5 minutes, 8) duration of labor and 9) perinatal problems requiring admission of the newborn.

Statistics. These outcome variables, in particular the number of days before term and birth weight were first correlated in a univariate way with the above-mentioned Pap smear characteristics. Confidence limits at $95 \%$ interval were added to the calculated differences and relative risks. The most relevant variables were combined in a general Pap smear score, which was termed 'vaginal eco-score' or VECOscore. The correlation of this VECO-score with the pregnancy outcome was tested by univariate analysis and standardized for the presence of positive or negative vaginal cultures. To exclude mutual interaction, stepwise multivariate analysis (Cox analysis) was performed, and linear regression analysis was done to calculate the relation between VECOscore and birth weight and time of delivery.

\section{RESULTS}

Mean gestational age at first visit was 15.8 (sd 10.1) weeks, a mean of 22.6 (sd 10) weeks remote from delivery. Mean gestational age at delivery was 38.9 (sd 3.2) weeks. Twenty-five delivered at 37 weeks or less (14\%).

Univariate analysis of the Pap smear variables compared with birth weight and number of days born before term are shown in Table 1. Women with normal flora (LBG I) seemed to deliver closer to term than women with higher

Table 1. Impact of Findings on Pap Smears Collected at First Prenatal Visit of 173 Women on Birth Weight and the Mean Number of Days of Delivery Before Expected Birth Date. Only Significant Differences are Shown. Bacterial Vaginosis as Diagnosed as Clue Cells on Microscopy Confirmed by either Clinical Criteria or by Heavy Growth of Gardnerella vaginalis on Vaginal Culture

\begin{tabular}{|c|c|c|c|c|c|}
\hline & $\mathbf{N}$ & Birth Weight (sd) & Difference (CL 95\%) & Days Pre-Term (sd) & Difference (CL 95\%) \\
\hline \multicolumn{6}{|c|}{ Grade of Lactobacillary Flora } \\
\hline I (normal) & 20 & $3293(500)$ & & $2.8(12)$ & \\
\hline II (intermediate) & 75 & $3328(516)$ & & $7.3(11)$ & \\
\hline III (disturbed) & 46 & $3243(489)$ & & $6.8(12)$ & \\
\hline \multicolumn{6}{|c|}{ Morphology of Lactobacilli } \\
\hline Normal type & 110 & $3340(523)$ & & $6.2(11)$ & \\
\hline Coarse type & 14 & $3213(478)$ & & $6.1(13)$ & \\
\hline Leptosomic type & 19 & $3149(506)$ & & $8.9(12)$ & \\
\hline \multicolumn{6}{|l|}{ Background Activity } \\
\hline Clean & 48 & $3288(570)$ & & $6.7(12)$ & \\
\hline Dirty & 61 & $3318(493)$ & & $7.7(12)$ & \\
\hline Cytolysis & 35 & $3432(457)$ & & $3.6(10)$ & \\
\hline Red blood cells & 16 & $3100(589)$ & & $8.2(12)$ & \\
\hline \multicolumn{6}{|c|}{ Epithelial Cell Abnormality } \\
\hline Normal & 166 & $3325(512)$ & & $5.8(11)$ & $12.9(3.8-22)$ \\
\hline Abnormal & 7 & $2948(524)$ & & $18.7(15)$ & \\
\hline \multicolumn{6}{|c|}{ Proportional Leukocytosis } \\
\hline$<10 / \mathrm{hpf}$ & 44 & $3444(504)$ & & $3.6(9.7)$ & \\
\hline$>10 / \mathrm{hpf},<10 /$ cell & 62 & 3367 (512) & $198(15-981)$ & $6.2(12)$ & \\
\hline$>10 /$ hpf, $>10 /$ cell & 61 & $3169(511)$ & $275(76-474)$ & $8.2(12)$ & \\
\hline \multicolumn{6}{|l|}{ Pathogens Visualized } \\
\hline None & 158 & $3323(521)$ & & $6.4(12)$ & \\
\hline Bacterial vaginosis & 18 & $3260(557)$ & & $5.8(10)$ & \\
\hline Candidiasis & 57 & $3179(551)$ & & $7.6(12)$ & \\
\hline Coccoid bacteria & 17 & 3254 (584) & & $6.6(14)$ & \\
\hline
\end{tabular}

hpf: microscopic high power field (400 times magnification) 
LBG's, but the difference was not significant. When present, abnormal morphology of the lactobacilli and the presence of red blood cells seemed to be associated with lower birth weight, but again no significant difference was found. The finding of epithelial cellular abnormalities resulted in lower birth weight $(\mathrm{p}=0.06)$ and more preterm delivery $(\mathrm{p}<$ 0.001 ). Presence of heavy vaginal leukocytosis (more than 10 leukocytes per epithelial cell) resulted in more preterm days at delivery and lower birth weight compared with when leukocytosis was less pronounced $(\mathrm{p}=0.03)$ or absent $(\mathrm{p}<$ 0.01).

Bacterial vaginosis at first prenatal visit was not associated with preterm birth or with decreased birth weight.

In composing the VECO-score, points were annotated to the lactobacillary grades (1 to 3 ), further augmented with 1 point if abnormal LB morphotypes, red blood cells, moderate leukocytosis or one pathogen was present, and 2 points when cellular abnormalities, severe vaginal leukocytosis or two different pathogens were present. One point was subtracted when lysis of epithelial cells was present (Table 2). Care was taken not to include clinical criteria, in order to enable the VECO-score to be calculated by a pathologist or technician without knowing the patient.

When linear regression was analyzed, a high correlation was found between the VECO-score and the mean birth weight $\left(\mathrm{R}^{2} 0.85\right)$ or the number of preterm days at delivery $\left(R^{2} 0.57\right.$, Fig. 1). After multivariate analysis (excluding the composing parameters of the VECO-score) the VECO-score remained the only predictor of early delivery $(p=0.0072)$, lower birth weight $(\mathrm{p}<0.0001)$, head circumference $(\mathrm{p}=0.0025)$ and delivery by cesarean section ( $\mathrm{p} 0.024$, Table 3). Low Apgar scores after 5 minutes showed a significant relationship with clinical signs of vaginitis $(\mathrm{p}=0.017)$, and borderline relationships with positive vaginal culture result $(\mathrm{p}=0.098)$ and previous antibiotherapy ( $\mathrm{p}$ $=0.075)$. Neonatal admission was related to parity ( $p=0.046)$ but not to any of the infectious parameters. The presence of anti-Chlamydia antibodies was weakly associated with preterm delivery $(\mathrm{p}=0.06)$. Receiving tocolytic treatment (ambulatory or in hospital) was significantly associated both with the presence of anti-Chlamydia IgG $(\mathrm{p}=0.01)$ and with the receipt of antibiotherapy during the course of pregnancy $(p=0.01)$. Chorioamnionitis was not related to any of the variables. The mean VECO-score of women delivering at 37 weeks or less was 2.9 (sd 2.5), and was not different from women delivering at term (3.2 (sd 2.5)).

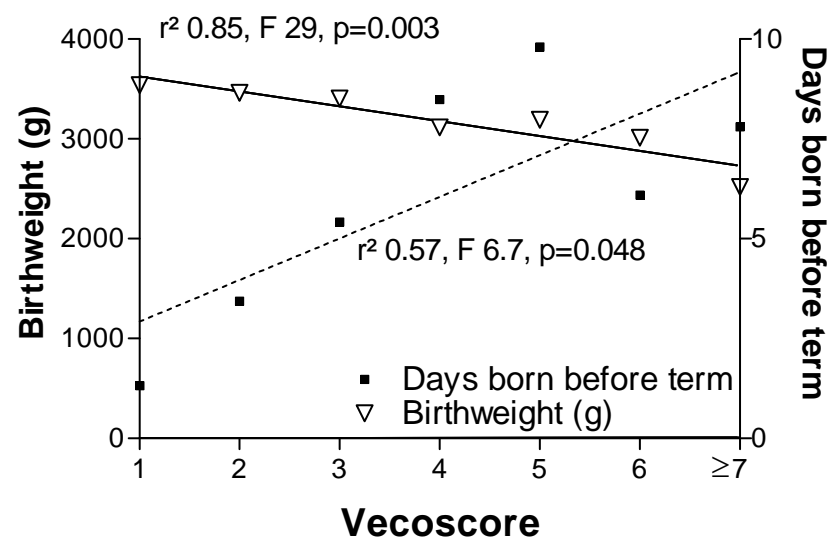

Fig. (1). Association between Vecoscore (see text) and birth weight (full line, $\nabla$ ) and between Vecoscore and the number of days remote from term at birth (dashed line, (2).

When a cut-off value of 4 was used (Table 4), a higher VECO-score was predictive for decreased birth weight $(\mathrm{p}<$ $0.01)$, earlier delivery $(p=0.06)$, neonatal head circumference ( $\mathrm{p}<0.01)$, and spontaneous $v s$ induced labor $(\mathrm{p}<0.01)$. There was no association with Apgar score, neonatal admission rate, cesarean section rate, preterm labor rate $(13 \%$ vs $7 \%, \mathrm{p}>0.05$ ) or chorioamnionitis.

We introduced stratification according to positive vaginal cultures in order to assess the influence of both vaginal cultures and the VECO score. Birth weight was decreased and delivery more preterm in the group with high VECO scores at first visit, irrespective of the results of the vaginal culture. Women with negative culture but a high VECO-score more often needed treatment for preterm labor than those with a low VECO score (11\% vs 4\%), but this difference was not significant. In this univariate approach, positive vaginal cultures were related to placental chorioamnionitis when both the high and the low VECO group were analyzed together ( $\mathrm{p}$ $<0.01$ ).

\section{DISCUSSION}

The expected finding that the presence of bacterial vaginosis as such would lead to more prematurity and lower birth weight was not confirmed in this study. The most obvious explanation is that our series was too small to show statistical power, because the relationship between BV and preterm

Table 2. Annotation of Prematurity Risk to the Variables from the Pap Smear. Total Score Equals the 'Vaginal Eco-Score"

\begin{tabular}{|c|c|c|c|c|c|}
\hline $\begin{array}{c}\text { Type of Microsorical } \\
\text { Abnormality }\end{array}$ & $\mathbf{- 1}$ & $\mathbf{0}$ & $\mathbf{+ 1}$ & $\mathbf{+ 2}$ \\
\hline \hline Lactobacillary grade & & & Normal & Intermediate & Disturbed \\
\hline Lactobacillary types & & Normal & Coarse or leptosomic & & \\
\hline Background activity & Lysis of epithelial cells & & Red blood cells & & \\
\hline Epithelial cell abnormality * & & Normal & & Abnormalities present & \\
\hline Any visible pathogenic growth ** & & No pathogens & One pathogen present & More than one pathogens & $>10 /$ cell \\
\hline Vaginal leucocytosis & & $<10 / \mathrm{hpf}$ & $>10 / \mathrm{hpf}$ and $<10 /$ cell & \\
\hline
\end{tabular}

*: Dysplasia or Dense Cytoplasmic Granules (Cfr. Text), ** : Bacterial Vaginosis, Trichomonas vaginalis, Coccoid (Aerobic Vaginitis) Flora or Candidiasis. hpf: microscopic high power field (400 times magnification). 
Table 3. Multivariate Analysis on Different Outcome Variables vs Age, Parity and Variables of Genital Infection at First Prenatal Visit. Significant Associations are Highlighted

\begin{tabular}{|c|c|c|c|c|c|c|c|c|c|c|c|c|c|c|c|c|c|c|c|c|c|}
\hline \multirow[t]{2}{*}{$\begin{array}{l}\text { Outcome } \\
\text { Variable }\end{array}$} & \multicolumn{3}{|c|}{ Birth Weight } & \multicolumn{3}{|c|}{ Apgar 5} & \multicolumn{3}{|c|}{$\begin{array}{c}\text { Days } \\
\text { Before } \\
\text { Term } \\
\end{array}$} & \multicolumn{3}{|c|}{$\begin{array}{c}\text { Mode of } \\
\text { Delivery } \\
\text { (C-Section Rate) } \\
\end{array}$} & \multicolumn{3}{|c|}{$\begin{array}{c}\text { Neonatal } \\
\text { Admission } \\
\text { Rate }\end{array}$} & \multicolumn{3}{|c|}{$\begin{array}{c}\text { Use of } \\
\text { Tocolytics }\end{array}$} & \multicolumn{3}{|c|}{$\begin{array}{l}\text { Chorio- } \\
\text { Amnionitis }\end{array}$} \\
\hline & S-Est & $R^{2}$ & Prob & S-Est & $R^{2}$ & Prob & S-Est & $R^{2}$ & Prob & S-Est & $R^{2}$ & Prob & S-Est & $R^{2}$ & Prob & S-Est & $R^{2}$ & Prob & S-Est & $R^{2}$ & Prob \\
\hline Age & 0.02 & 0.1 & & 0.01 & 0.4 & & 0.00 & 0.91 & & 0.00 & 0.4 & & 0.00 & 0.7 & & 0.00 & 0.7 & & .02 & 00.3 & \\
\hline Parity & 0.00 & 0.8 & & 0.00 & 0.8 & & 0.00 & 0.7 & & 0.00 & 0.7 & & 0.24 & 0.06 & 0.046 & 0.01 & 0.3 & & 0.01 & 0.6 & \\
\hline $\begin{array}{c}\text { Clinical signs } \\
\text { of vaginitis }\end{array}$ & 0.00 & 0.8 & & 0.28 & 0.08 & 0.017 & 0.02 & 0.2 & & 0.02 & 0.19 & & 0.00 & 0.9 & & 0.00 & 0.7 & & 0.00 & 0.8 & \\
\hline $\begin{array}{l}\text { Positive vaginal } \\
\text { culture result }\end{array}$ & 0.00 & 0.96 & & 0.19 & 0.04 & & 0.00 & 0.6 & & 0.03 & 0.11 & & 0.00 & 0.6 & & 0.00 & 0.7 & & 0.01 & 0.5 & \\
\hline $\begin{array}{c}1 \mathrm{~h} \mathrm{RBC} \\
\text { sedimentation }\end{array}$ & 0.00 & 0.99 & & 0.01 & 0.3 & & 0.00 & 0.91 & & 0.03 & 0.1 & & 0.00 & 0.6 & & 0.00 & 0.7 & & 0.01 & 0.7 & \\
\hline $\begin{array}{l}\text { VECO- } \\
\text { score }\end{array}$ & -0.5 & 0.25 & $<0.0001$ & 0.00 & 0.8 & & 0.31 & 0.1 & 0.0072 & -0.27 & 0.07 & 0.024 & 0.01 & 0.3 & & 0.00 & 0.6 & & 0.03 & 0.3 & \\
\hline
\end{tabular}

RBC: red blood cells.

Table 4. Association of Pregnancy Outcome with Vaginal Ecology Score (VECO) and Vaginal Culture Results

\begin{tabular}{|c|c|c|c|c|c|c|c|c|c|c|c|}
\hline $\begin{array}{l}\text { Vaginal Infec- } \\
\text { tious Marker }\end{array}$ & $\mathbf{N}$ & Birth Weight (sd) & $\begin{array}{c}\text { Head } \\
\text { Circumference } \\
\text { (sd) }\end{array}$ & $\begin{array}{c}\text { Apgar at } 5 \\
\text { min (sd) }\end{array}$ & $\begin{array}{c}\text { Neonatal } \\
\text { Admission } \\
(\%)\end{array}$ & $\begin{array}{c}\text { C-Section } \\
(\%)\end{array}$ & $\begin{array}{c}\text { ROM } \\
>12 \mathrm{~h} \\
(\%)\end{array}$ & $\begin{array}{c}\text { Preterm } \\
\text { Labor } \\
(\%)\end{array}$ & $\begin{array}{c}\text { Days } \\
\text { Before } \\
\text { Term at } \\
\text { Birth (sd) }\end{array}$ & $\begin{array}{c}\text { Induction } \\
\text { of } \\
\text { Labor }(\%)\end{array}$ & $\begin{array}{c}\text { Placenta } \\
\text { Chorio- } \\
\text { amnionitis } \\
(\%)\end{array}$ \\
\hline Vaginal culture - & 48 & $3468(458)$ & $34.2(1.4)$ & $8.5(1.4)$ & $6(13 \%)$ & $8(17 \%)$ & $6(13 \%)$ & $2(4 \%)$ & $2.1(8.3)$ & $12(25 \%)$ & $2 / 38(5 \%) \$$ \\
\hline Vaginal culture + & 32 & $3510(473)$ & $34.9(1.3)$ & $8.9(1.0)$ & $6(21 \%)$ & $7(22 \%)$ & $3(9 \%)$ & $4(13 \%)$ & $3.5(9.5)$ & $10(31 \%)$ & $4 / 31(13 \%)$ \\
\hline Vaginal culture - & 47 & $3191(509) *$ & $33.7(4.2)$ & $8.5(1.7)$ & $6(13 \%)$ & $3(6 \%)$ & $6(13 \%)$ & $5(11 \%)$ & $8.0(11) *$ & $11(23 \%)$ & $1 / 30(3 \%)$ \\
\hline Vaginal culture + & 31 & $3031(517) *$ & $33.3(1.8)$ & $8.9(1.2)$ & $8(26 \%)$ & $5(16 \%)$ & $6(19 \%)$ & $5(16 \%)$ & $9.9(16) *$ & $8(26 \%)$ & $4 / 19(21 \%)$ \\
\hline \multicolumn{12}{|l|}{ TOTAL } \\
\hline VECO-score $<4$ & 95 & $3460(457)$ & $34.5(1.3)$ & $8.8(1.2)$ & $15(16 \%)$ & $16(17 \%)$ & $11(12 \%)$ & $7(7 \%)$ & $3.2(8.8)$ & $28(29 \%)$ & $8 / 85(9 \%)$ \\
\hline
\end{tabular}

delivery has been demonstrated by others [12-16]. Also, the sampling in this study was performed at the first prenatal visit, a mean of 23 weeks remote from delivery, whereas many studies describing the relationship of BV and prematurity are either case-control studies, or diagnose BV at later then 20 gestational weeks up to delivery. A convincing association of $\mathrm{BV}$ at first consultation ( 8 to 17 weeks) with premature labor and preterm delivery was presented by Kurki et al. [14] in a well designed prospective study.
However, other studies don't seem to confirm the unequivocal role of BV in the causation of preterm birth [4, 17]. Bacterial vaginosis is known to express a bizarre and illunderstood spontaneous cure and relapse rate $[19,20]$, in general BV leading to a decrease in its prevalence from the first towards the third trimester [19]. Treatment with oral metronidazole, even in repeated courses, is not able to cure $\mathrm{BV}$ in at least $15 \%$ of the pregnant women [21].

Hay et al. described that disturbed vaginal microflora was a risk factor for mid trimester abortion and preterm de- 
livery [11], findings very similar to our own group's [6]. They concluded, however, that 'late miscarriage and preterm delivery are associated with the presence of bacterial vaginosis early in pregnancy', thereby equating 'abnormal bacterial colonization' with 'bacterial vaginosis'. This may not always be justified [22]. Therefore, the real anaerobic bacterial vaginosis, as proposed by Blackwell et al. [23] must be viewed as a clinical condition, caused by Gardnerella vaginalis, Bacteroides and all associated anaerobes, with cluecell positive vaginal discharge [18], raised $\mathrm{pH}$ and a fishy smell [24]. In this study we failed to link prematurity with (anaerobic) bacterial vaginosis. On the other hand we were able to correlate disturbed flora with gestational age at delivery and birth weight. Disturbed vaginal flora (LBG III) not only entangles BV, group B streptococci and almost all sexually transmitted diseases, but also aerobic vaginitis, in its extreme form also named 'desquamate atrophic vaginitis' $[25,26]$, may be a part of it [27]. The association with nonBV microorganisms is even more likely when prominent leukocytosis is also present. In a recent study using fresh smear microscopy we were also able to detect other abnormal flora types than full blown BV, such as partial BV and aerobic vaginitis, to be important marker of preterm delivery risk in low risk women [28].

One of the uncommon findings in this study was the relationship of increased vaginal leukocytosis with impaired pregnancy outcome. Previous studies often failed to quantify the vaginal leukocyte count in a reproducible manner. By using the high power field as a denominator for counting low numbers of leukocytes ( $<10$ per hpf), and the epithelial cell for high numbers (>10 per hpf) we may have overcome this drawback. As said above, the presence of high leukocytosis in LBG III patients is not suggestive of pure BV, where the absence of leukocytes is striking and almost typical.

Despite the disadvantage of low numbers to fit the detection power, we discovered that a significant impact on the course and outcome of the pregnancy was obtained by combining several criteria into a VECO-score. Composing the VECO-score is easy, and any routine microscopist, gynecologist or pathologist, already subconsciously takes note of all these items, but fails to use them in a combined mode. If confirmed in larger series, the effort to use more information from Pap smears, Gram or wet-mounts may produce a significant difference for the pregnant women, as further diagnostic investigation and intervention with suitable antibiotics could follow promptly. There is no reason to believe that other techniques to sample and study vaginal flora, such as Gram stain, or wet wount of fresh vaginal fluid would be less suitable for this purpose. The only criterion that would have to be dropped in such circumstances, would be the 'cellular abnormality' sign, which cannot be judged well by other techniques than Pap smears.

Studies have already shown reduced prematurity rates due to antibiotherapy during pregnancy. Selection of high risk groups, at no extra expense, may further adjust the type of treatment given, the intensity of the supervision of the pregnancy and cut costs further.

The association between VECO and C-section rate could be explained in many ways, and is likely to be influenced by co-factors not included in the multivariate analysis. If the predominant indications for $\mathrm{C}$-section were protracted labor and fetal discomfort, ascending infection and chorioamnionitis would have to be involved [1] and be associated with high VECO scores, but this was not the case.

The fetal head circumference was lower in the group with high VECO-scores. Its connection with decreased birth weight suggests prematurity rather than dysmaturity to be the cause of lower birth weight, as due to the brain-sparing effect; intrauterine growth retardation would be marked by a reversed abdomen to head circumference ratio.

We conclude that the combination of several variables found by microscopy enhances the specificity of observations related to vaginal ecology and so allows more precise prediction of the risk of early delivery and decreased birth weight.

\section{REFERENCES}

[1] Sweet RL, Gibbs RS. Intra-amniotic infection (intrauterine infection late in pregnancy). In: Infectious Diseases of the Female Genital Tract, $3^{\text {rd }}$ ed., Williams \& Wilkins, Baltimore 1995; 548-77.

[2] Lockwood CJ. Recent advances in elucidating the pathogenesis of preterm delivery, the detection of patients at risk and preventive therapies. Curr Opin Obstet Gynecol 1994; 6: 7-18.

[3] McGregor JA, French JI, Reller B, Todd JK, Makowski EL. Adjunctive erythromycin treatment in idiopathic preterm labor: results of a randomised, double-blinded, placebo-controlled trial. Am J Obstet Gynecol 1986; 154: 98-102.

[4] Schröder K. Zur pathogenese und Klinik des vaginalen Vaginalbiocoenose auf sechs grundbilder. Zentralbl Gynakol 1921; 45: 135061.

[5] Donders GGG. Microscopy of the bacterial flora on fresh vaginal smears. Infect Dis Obstet Gynecol 1999; 7: 126-7.

[6] Donders G, De Wet GH, Hooft P, Desmyter J. Lactobacilli in Papanicolaou smears, genital infections, and pregnancy. Am J Perinatol 1995; 10: 358-61.

[7] Donders G, Desmyter J, De Wet GH, Van Assche FA. The association of gonorrhoea and syphilis with preterm birth and low birth weight. Genitourin Med 1993; 69: 97-100.

[8] Donders G, Moerman P, De Wet GH, Hooft P, Goubau P. Chlamydia cervicitis, associated chorioamnionitis and neonatal infections. Arch Gynecol Obstet 1991; 249: 79-85.

[9] Donders GGG, Van Bulck B, Caudron J, Londers L, Vereecken A, Spitz B. Bacterial vaginosis and mycoplasmata increase the risk of spontaneous abortion. Am J Obstet Gynecol 2000; 183: 431-7.

[10] Donders GGG, Odds A, Vereecken A, et al. Abnormal vaginal flora in the first trimester, but not full blown bacterial vaginosis is associated with preterm birth. Prenat Neonatal Med 1998; 3: 58893.

[11] Hay PE, Lamont RF, Taylor-Robinson D, Morgan DJ, Ison C, Pearson J. Abnormal bacterial colonisation of the genital tract and subsequent preterm delivery and late miscarriage. Br Med J 1994; 308: 295-8.

[12] Mc Gregor JA, French JI, Parker R, et al. Prevention of premature birth by screening and treatment for common genital tract infections. Am J Obstet Gynecol 1995; 173: 157-67.

[13] Martius J, Krohn MA, Hillier SL, Stamm WE, Holmes KK, Eschenbach DA. Relationships of vaginal Lactobacillus species, cervical Chlamydia trachomatis and bacterial vaginosis to preterm birth. Obstet Gynecol 1988; 71: 89-95.

[14] Kurki T, Sivonen A, Renkonen OV, Savia E, Ylikorkala, O. Bacterial vaginosis in early pregnancy and pregnancy outcome. Obstet Gynecol 1992; 80: 173-7.

[15] Gravett MG, Nelson HP, De Rouen T, Critchlow CC, Eschenbach DA, Holmes KK. Independent associations of bacterial vaginosis and Chlamydia with adverse pregnancy outcome. JAMA 1986; 256: 1899-903.

[16] Morales WJ, Schorr J, Albretten J. Effect of metronidazole in patients with preterm birth on proceeding pregnancy and bacterial vaginosis: a placebo-controlled, double blind study. Am J Obstet Gynecol 1994, 171: 345-9.

[17] Carey JC, Klebanoff MA, Hauth JC, et al. Metronidazole to prevent preterm delivery in pregnant women with asymptomatic bacterial vaginosis. N Engl J Med 2000; 342: 534-40. 
[18] Van der Meijden WI. Clinical aspects of Gardnerella vaginalisassociated vaginitis. A review of the literature. Scand J Urol Nephrol Suppl 1985; 86: 135-41.

[19] Platz-Christensen J-J, Pernevi P, Hagmar B, Andersson E, Brandberg A, Wiqvist N. A longitudinal follow-up of bacterial vaginosis during pregnancy. Acta Obstet Gynecol Scand 1993; 72: 99-102.

[20] Hillier SL, Krohn MA, Nugent RP, Gibbs RS. Characteristics of three vaginal flora patterns assessed by Gram stain among pregnant women. Am J Obstet Gynecol 1992; 166: 938-44.

[21] McDonald HM, O'Loughlin JA, Jolley PT, Vigneswaran R, McDonald PJ. Changes in vaginal flora during pregnancy and association with preterm birth. J Infect Dis 1994; 170: 724-8.

[22] Donders GGG. Bacterial vaginosis during pregnancy: screen and treat? Eur J Obstet. Gynecol Reprod Biol 1999; 83: 1-4.

[23] Blackwell IL, Phillips I, Fox AR, Barlow D. Anaerobic vaginosis (non-specific vaginitis): clinical, microbiological and therapeutic findings. Lancet 1983; 2: 1379-82.
[24] Amsel R, Totten PA, Spiegel CA, Chen K, Eshenbach DA, Holmes KK. Nonspecific vaginitis. Diagnostic criteria and microbial and epidemiological associations. Am J Med 1983; 74: 14-22.

[25] Gardner HL. Desquamative inflammatory vaginitis: a newly defined entity. Am J Obstet Gynecol 1968; 102: 1102-5.

[26] Sobel JD. Desquamative inflammatory vaginitis: a new subgroup of purulent vaginitis responsive to topical $2 \%$ clindamycin therapy. Am J Obstet Gynecol 1994; 171: 1215-20.

[27] Donders GGG, Vereecken A, Bosmans E, Dekeersmaecker A Salembier G, Spitz B. Definition of a type of abnormal vaginal flora that is distinct from bacterial vaginosis: aerobic vaginitis. Br J Obstet Gynecol 2002; 109: 1-10.

[28] Donders GGG, Van Calsteren C, Bellen G, et al. Predictive value for preterm birth of abnormal vaginal flora, bacterial vaginosis and aerobic vaginitis during the first trimester of pregnancy. Br J Obstet Gynecol 2008, in press.

(C) Donders et al:; Licensee Bentham Open.

This is an open access article licensed under the terms of the Creative Commons Attribution Non-Commercial License (http://creativecommons.org/licenses/bync/3.0/) which permits unrestricted, non-commercial use, distribution and reproduction in any medium, provided the work is properly cited. 